American Journal of Biochemistry and Biotechnology 7 (2): 74-83, 2011

ISSN 1553-3468

(C) 2011 S. Shrivastava, This open access article is distributed under a Creative Commons Attribution

(CC-BY) 3.0 license

\title{
S-Allyl-Cysteines Reduce Amelioration of Aluminum Induced Toxicity in Rats
}

\author{
Sadhana Shrivastava \\ Reproductive Biology and Toxicology Laboratory, \\ School of Studies in Zoology, Jiwaji University, Gwalior-474011, India
}

\begin{abstract}
Problem statement: Aluminum (Al) is a trivalent cation found in its ionic form in most kinds of animal tissues and in natural waters everywhere. Approach: It is a potent neurotoxin and has been associated in the pathogenesis of several clinical disorders including Alzheimer's disease. Results: The aim of the study was to demonstrate the protective effect of S-Allyl-Cysteines (SAC) against Al-induced toxicity in rat model on certain biochemical parameters, lipid peroxidation and oxidative stress enzymes of white albino rats. Six rats per group were divided into various treatment groups. Group one rats were given normal saline and served as control group. Group two animals received $\mathrm{Al}$ as aluminum nitrate $32.5 \mathrm{mg}$ (i.p.) for the induction of toxicity. Group three to five received different doses of SAC $\left(25,50\right.$ and $\left.100 \mathrm{mg} \mathrm{kg}^{-1}\right)$ for 3 days after $24 \mathrm{~h}$ of Al toxicity. Rats were orally administered their respective doses every day for 3 days. Evaluations were made in blood and tissues. The activity of Acetylcholinesterase (AchE) was inhibited in all the parts of brain after Al intoxication. Significant rise were observed the Activities of Serum Transaminases (AST and ALT) after toxicant exposure. The activity of $\delta$-Aminolevulinic acid Dehydratase (ALAD) in blood and $\delta$ Aminolevulinic Acid Synthetase (ALAS) in brain was decreased after Al exposure. Al significant increased cholesterol, triglyceride, creatinine and urea level in serum. TBARS level was significantly higher and GSH content were significantly lower during toxicity. Total and esterified cholesterol in liver, kidney and brain were increased after $\mathrm{Al}$ exposure. Histopathological changes in liver, kidney and brain were also recouped with the therapy. Conclusion/Recommendations: Our data proved that $\mathrm{SAC}$ which is a bioactive and bioavailable component of garlic has organosulfur compounds which regulates the thiol status of the cell and scavenges free radicals and work as an antioxidant. Thus SAC effectively reduces cognitive dysfunction and oxidative damage induced by Al.
\end{abstract}

Key words: S-Allyl-Cysteines (SAC), aluminum, oxidative stress, liver, kidney and brain

\section{INTRODUCTION}

Recent trends in controlling and treating diseases tend to favor natural antioxidant compounds rather than synthetic ones. Garlic (Allium sativum) is a commonly worldwide used food and its medical properties have been well recognized since the ancient times (Craig and Beck, 1999). Many beneficial health properties of garlic are attributed to organosulfur compounds, particularly to sulfur-bearing compounds such as allicin, S-AllylCysteines (SAC), Diallyl-Di-Sulfide (DADS) and Diallyl-Sulfide (DAS) .The protective actions of SAC in the basal memory responses, ischemic brain, brain edema, on learning defects (Nishiyama et al., 2001) and neurons against TM-induced neurotoxicity is reported (Kosuge et al., 2006). It also protects the Abeta-induced neuronal cell death (Ishige et al., 2007). Garlic is also one of the well known plants with multiple beneficial effects such as antimicrobial (Johnson and Vaughn, 1969), antithrombotic, hypolipidemic (Bordia et al.,
1975), antiarthritic, hypoglycemic (Jain and Vjas, 1975) anticarcinogenic (Hussain et al., 1990), antifungal (Amer et al., 1980), anti-atherosclerotic (Bordia and Verma, 1980) an antioxidant against free radicals (Morihara et al., 2006; Banerjee et al., 2003). It has been shown to be significantly effective against lead, cadmium, nickel, chromium, arsenic and mercury poisoning (Senapati et al., 2001; Tandon et al., 2001; Das et al., 2009; 2008; Kalayarasan et al., 2008; Lee et al., 1999; Metwally et al., 2009).

Aluminium ( $\mathrm{Al})$ is a ubiquitous element and has been proposed as an environmental factor that may contribute to some neurodegenerative diseases and affects several enzymes and other biomolecules relevant to Alzheimer's disease. It is present in many manufactured foods, medicines, cheese, tea, cosmetics and is also added to drinking water during purification purposes (Al-Hashem, 2009a; 2009b; Newairy et al., 2009; Yousef and Salama, 2009). Different forms of Al are environmental xenobiotics that induce free radical- 
mediated cytotoxicity and neurotoxicity (Yousef and Salama, 2009; Prakash and Kumar, 2009; Kan et al., 2010; Bihagi et al., 2009). Also, increased aluminium burdens, can cause neurological symptoms, biochemical responses leading to unhealthy bone metabolism andlearning disabilities in children (Isaacson and Jensen, 1994). The high aluminium diet led to increased central nervous system aluminium concentration and altered concentrations of the essential trace elements iron and manganese (Goulb et al., 1995), neutrophilic inflammation and oxidative stress in welders of aircraft plant (Stark et al., 2009), deregulation of cell signaling thus impairment of neurotransmission (Verstraeten et al., 2008). Aluminum may have a direct effect on iron metabolism; it influences absorption of iron via the intestine, it hinders iron's transport in the serum and it displaces iron's binding to transferring (Mostaghie and Skillen, 1986) The aim of the study was to evaluate the anti-oxidant potential of S-Allyl-Cysteines (SAC) against aluminium-induced toxicity in rat model by evaluating antioxidant enzymes activities, markers of haem synthesis, acetycholenistrase in brain, LFT's and KFT's. The changes were substantiated by histopathological findings.

\section{MATERIALS AND METHODS}

Experimental animals: Sprague Dawley female albino rats weighing $160 \pm 10 \mathrm{~g}$ from department animal facility were selected. They received a standard pellet diet (Pranav Agro Industries, New Delhi, India having metal contents in ppm dry weight $\mathrm{Cu}, 10 ; \mathrm{Mn}, 33 ; \mathrm{Zn}$, 45; and Co, 5) and drinking water ad libitum. Animals used in this study were treated and cared for in accordance with the guidelines recommended by the Committee for the Purpose of Control and Supervision of Experiments on Animals (CPCSEA), Government of India, Ministry of Culture, Chennai.

Chemicals: Aluminium nitrate (Qualigens), other analytical grade laboratory reagents were procured from Merck (Germany) HiMedia and Glaxo chemical (India) and SAC was procured from Prof Xiong.

\section{Experimental design:}

Group 1: Were control rats received a single daily dose of normal saline orally.

Group 2: Were rats given a daily single dose of aluminum nitrate at $32.5 \mathrm{mg} \mathrm{kg}^{-1}\left(1 / 2 \mathrm{LD}_{50}\right.$ i.p. once only) and name $\mathrm{Al}$ treated rats.
Group 3-5: Were rats given a dose of SAC at 25, 50 and $100 \mathrm{mg} \mathrm{Kg}^{-1}$, p.o. for 3 days

Animals of all the groups were sacrificed after 48 hours of last treatment and different biochemical analyses were performed.

Biochemical assays: Blood was collected directly from the heart by puncturing the retro-orbital venosus sinus (Riley, 1960) and serum was isolated for the estimation of AST and ALT (Reitman and Frankel, 1957) and $\delta$-Aminolevulinic Acid Dehydratase (ALAD) (Berlin and Schaller, 1974). Serum cholesterol, Triglyceride (TG), creatinine and urea (kit method) were estimated by autoanalyser. The activity of Acetylcholinesterase (AchE) was determined in different parts of brain (Ellman et al., 1961). Homogenate in an isotonic solution was processed for total and esterified cholesterol (Zlatkis et al., 1953). Hepatic, renal and cerebral LPO (Sharma and Krishna Murthy, 1968) and GSH (Brehe and Burch, 1976) was also estimated. The activity of $\delta$-Aminolevulinic Acid Synthetase (ALAS) was also determined in brain (Maines, 1980).

Histopathological assays: Liver, kidney and brain were dissected out washed in saline and fixed in Bouin's fluid, embedded in paraffin, sectioned at $6 \mu \mathrm{m}$ and stained with haemotoxylin and eosin for examination by light microscopy.

Statistical analysis: $P$ values at the level of $\leq 0.05$ were evaluated by student's $t$ test. Significance of the difference among various groups was evaluated by one way Analysis of Variance (ANOVA) @ $\mathrm{F}=\mathrm{P} \leq 0.05$ (Snedecor and Cochran, 1989).

\section{RESULTS}

Biochemical observations: The results demonstrates that the toxicity produced by $\mathrm{Al}$ was associated with a variety of biochemical abnormalities and these could usually be attributed to the release of intracellular constituents in to the circulation, following loss of integrity of the cell membrane or interference with normal metabolism and function. Table 1 and 2 depicts that administration of $\mathrm{Al}$ elevated the activity of serum AST, ALT and LDH where as serum protein was found to be depleted. These results indicate a protective effect of $\mathrm{S}$-allylcysteine $(\mathrm{P} \leq 0.05)$ on the membrane by virtue of its antioxidant property. Toxicant induced depletion in the activity of ALAD and serum proteins. SAC therapy showed recovery pattern, this was significant at 
higher doses. The serum profile of $\mathrm{Al}$ exposed rats reveals significant rise in triglyceride, cholesterol, creatinine and urea as kidney markers $(\mathrm{P} \leq 0.05)$. SAC therapy showed values near to the control at higher doses (Table 2). Al is highly neurotoxic element and has been suggested to play a role in degeneration of nerve cells in the brain of human and experimental animals. It reduced the AChE activity of cerebellum (hind brain) when compared to controls. At the same time the mid-brain and cortex (for brain) enzyme activity was also reduced $(\mathrm{p} \leq 0.05)$. Toxicant also caused depletion in ALAS in brain. Treatment of SAC significantly restored these parameters (Table 3).

Further, we assessed oxidative stress parameters and antioxidant activity in the liver and the kidney and the results are summarized in table 4. Hepatic, renal and cerebral (brain) LPO was significantly increased after $\mathrm{Al}$ exposure whereas hepatic, renal and cerebral GSH was significantly decreased. However, combination of garlic extract reduced TBARS concentration and restored the levels of GSH. Results show that total cholesterol and esterified cholesterol in the liver, kidney and brain was increased after toxicant administration. These results show that, SAC has a protective effect on the Al induced changes in the lipid levels (Table 5). Control rats had extremely small amount of $\mathrm{Al}$ in liver, kidney and brain. Exposure led to a pronounced increase in $\mathrm{Al}$ body burden $(\mathrm{P} \leq 0.05)$ in all the organs. The accumulation of $\mathrm{Al}$ was in the order liver $>$ kidney $>$ brain. Therapy of SAC was significantly effective $(\mathrm{P} \leq 0.05)$ in removing $\mathrm{Al}$ from all the organs significantly $(\mathrm{P} \leq 0.05)$ (Table 6$)$. An overview of the effect of extract treatment in aluminium intoxicated rats reveals that higher dose were significantly effective when compared with other doses.

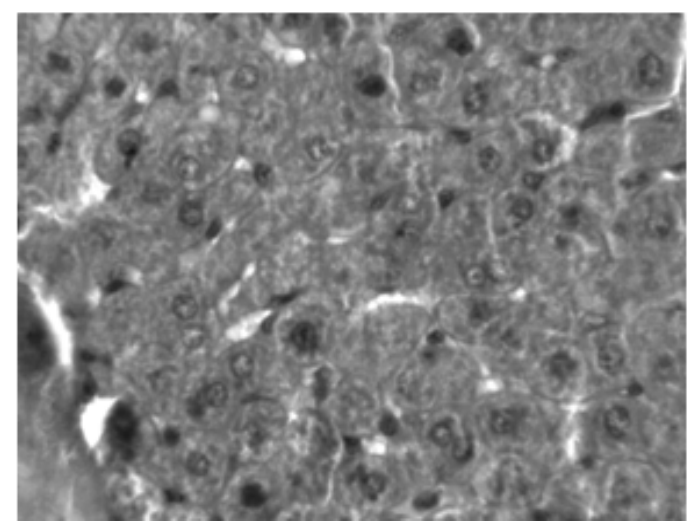

Fig. 1: Hypertrophy of hepatocytes, hyperchromatic nuclei with fluid filled sinus was seen in liver after $\mathrm{Al}$ exposure (X400)
Histopathological observations: Aluminum exposure showed, disturbed chord arrangement, enlargement in sinusoidal spaces, hypertrophy of hepatocytes with hyperchromatic nuclei. Kupffer cells were increased in number (Fig. 1). At places bile duct proliferation and inflammatory cells were seen. At low doses therapy showed mild cytoplasmic vacuolation and granulation in hepatocytes. However the highest dose showed hexagonal hepatocytes with clear nucleus (Fig. 2). Al treatment showed higher degree of degeneration in cortex and medullary region. Bowman's capsules showed hypertrophy, disturbed endothelial lining and cytoplasmic vacuolation was observed (Fig. 3). At low dose therapy improvement was seen, however at the highest dose endothelial lining was maintained, Bowman's capsules was recouped (Fig. 4).

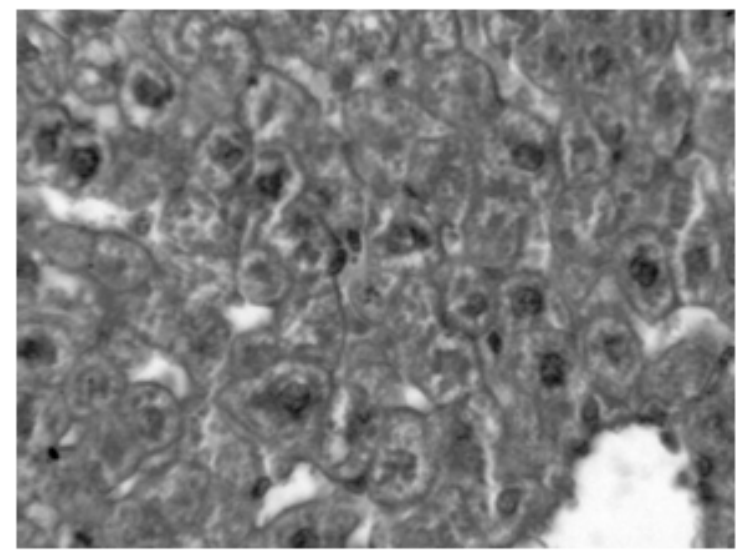

Fig. 2: $\mathrm{Al}\left(\mathrm{NO}_{3}\right)_{3}+\mathrm{SAC}_{100}$ showed hexagonal hepatocytes and clear sinus (X400)

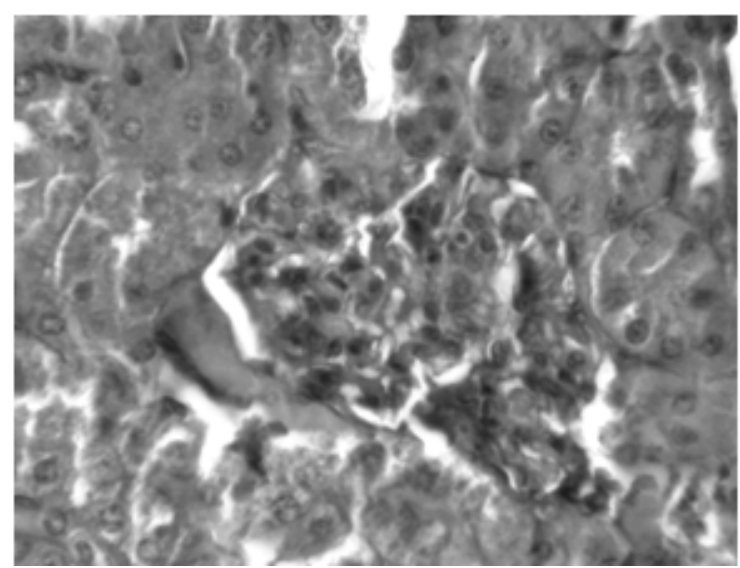

Fig. 3: Al exposure increased cellularity in glomeruli and distorted endothelial lining (X400) 
Am. J. Biochem. \& Biotech., 7 (2): 74-83, 2011

Table1: Effect of SAC against Al treated rats in ALAD and serum transaminases

\begin{tabular}{lcrr}
\hline Treatments & $\begin{array}{l}\text { ALAD } \\
\left(\mathrm{n} \mathrm{mol} \mathrm{min} \mathrm{mL}^{-1} \text { erytrhocytes }\right)\end{array}$ & $\begin{array}{c}\text { AST } \\
\left(\mathrm{IU} \mathrm{L}^{-1}\right)\end{array}$ & $\begin{array}{c}\text { ALT } \\
\left(\mathrm{IU} \mathrm{L}^{-1}\right)\end{array}$ \\
\hline Control & $7.80 \pm 0.43$ & $67.3 \pm 3.72$ & $41.2 \pm 2.27$ \\
$\mathrm{Al}$ & $3.20 \pm 0.17^{\#}$ & $157.0 \pm 8.67^{\#}$ & $127.0 \pm 7.02^{\#}$ \\
$\mathrm{Al}+\mathrm{SAC}_{25}$ & $4.23 \pm 0.23^{*}$ & $122.0 \pm 6.74^{*}$ & $66.9 \pm 3.69^{*}$ \\
$\mathrm{Al}+\mathrm{SAC}_{50}$ & $4.91 \pm 0.27^{*}$ & $116.0 \pm 6.41^{*}$ & $66.0 \pm 3.64^{*}$ \\
$\mathrm{Al}+\mathrm{SAC} 100$ & $5.96 \pm 0.32^{*}$ & $116.0 \pm 6.41^{*}$ & $55.6 \pm 3.07^{*}$ \\
Anova (F-Value) & $40.80^{\Theta}$ & $28.2^{\Theta}$ & $70.9^{\Theta}$ \\
\hline
\end{tabular}

Values are mean \pm S.E., $\mathrm{N}=6$. \#: $\mathrm{p} \leq 0.05$ vs control group; *: $\mathrm{p} \leq 0.05 \mathrm{Vs} \mathrm{Al}$ administered group. ANOVA (F-values) @: Significant at $5 \%$ level

Table 2: Effect of SAC against Al treated rats in urea, creatinine, triglycerides \& cholesterol in serum

\begin{tabular}{|c|c|c|c|c|}
\hline Treatments & $\begin{array}{l}\text { Urea } \\
\left(m g \mathrm{dL}^{-1}\right)\end{array}$ & $\begin{array}{l}\text { Creatinine } \\
\left(\mathrm{mg} \mathrm{dL}^{-1}\right)\end{array}$ & $\begin{array}{l}\text { Triglycerides } \\
\left(\mathrm{mg} \mathrm{dL}^{-1}\right)\end{array}$ & $\begin{array}{l}\text { Cholesterol } \\
\left(\mathrm{mg} \mathrm{dL}^{-1}\right)\end{array}$ \\
\hline Control & $19.8 \pm 1.09$ & $0.43 \pm 0.02$ & $68.80 \pm 3.80$ & $46.9 \pm 2.59$ \\
\hline $\mathrm{Al}$ & $55.8 \pm 3.08^{\#}$ & $0.50 \pm 0.02^{\#}$ & $94.20 \pm 5.20^{\#}$ & $75.0 \pm 4.14^{\#}$ \\
\hline $\mathrm{Al}+\mathrm{SAC}_{25}$ & $42.6 \pm 2.35 *$ & $0.45 \pm 0.02 *$ & $84.40 \pm 4.66 *$ & $53.2 \pm 2.94 *$ \\
\hline $\mathrm{Al}+\mathrm{SAC}_{50}$ & $42.0 \pm 2.32 *$ & $0.44 \pm 0.02 *$ & $77.00 \pm 4.25^{*}$ & $51.8 \pm 2.86^{*}$ \\
\hline $\mathrm{Al}+\mathrm{SAC}_{100}$ & $41.3 \pm 2.28 *$ & $0.44 \pm 0.02 *$ & $72.30 \pm 3.99 *$ & $48.1 \pm 2.65^{*}$ \\
\hline Anova (F-Value) & $37.3^{@}$ & $1.47^{\mathrm{ns}}$ & $6.350^{@}$ & $16.6^{@}$ \\
\hline
\end{tabular}

Values are mean \pm : SE, $N=6 .{ }^{\#}: \mathrm{p} \leq 0.05$ Vs control group; $*: \mathrm{p} \leq 0.05 \mathrm{Vs}$ Al administered group; ANOVA (F-values) ${ }^{\circledR}:$ Significant, ${ }^{\text {ns }}$ : Non significant at $5 \%$ level

Table 3: Effect of SAC against aluminium treated animals in Acetyl Cholinesterase in brain

\begin{tabular}{|c|c|c|c|c|}
\hline \multirow[b]{2}{*}{ Treatments } & \multicolumn{2}{|c|}{$\begin{array}{l}\text { Acetyl Cholinesterase } \\
\left(\mu \text { mole } \mathrm{min}^{-1} \mathrm{mg}^{-1} \text { protein }\right)\end{array}$} & \multicolumn{2}{|c|}{$\begin{array}{l}\text { ALAS } \\
\text { (n mol min }{ }^{-1} \mathrm{mg}^{-1} \text { protein) }\end{array}$} \\
\hline & Fore brain & Mid brain & Hind brain & Fore brain \\
\hline Control & $40.0 \pm 2.21$ & $20.40 \pm 1.12$ & $39.0 \pm 2.15$ & $11.80 \pm 0.65$ \\
\hline $\mathrm{Al}$ & $17.6 \pm 0.97^{\#}$ & $9.44 \pm 0.52^{\#}$ & $20.3 \pm 1.22^{\#}$ & $4.00 \pm 0.22^{\#}$ \\
\hline $\mathrm{Al}+\mathrm{SAC}_{25}$ & $27.6 \pm 1.53^{*}$ & $11.90 \pm 0.65^{*}$ & $26.2 \pm 1.44 *$ & $9.46 \pm 0.52 *$ \\
\hline $\mathrm{Al}+\mathrm{SAC}_{50}$ & $29.6 \pm 1.63^{*}$ & $12.70 \pm 0.70 *$ & $28.3 \pm 1.56^{*}$ & $9.93 \pm 0.54 *$ \\
\hline $\mathrm{Al}+\mathrm{SAC}_{100}$ & $30.6 \pm 1.69 *$ & $15.30 \pm 0.84 *$ & $30.5 \pm 1.68 *$ & $10.20 \pm 0.56$ \\
\hline Anova & $27.9^{@}$ & $32.70^{@}$ & $21.0^{@}$ & $38.70^{@}$ \\
\hline
\end{tabular}

(F-Value) Values are mean \pm : SE, $\mathrm{N}=6 .^{*}: \mathrm{p} \leq 0.05 \mathrm{Vs}$ control group, $* \mathrm{p} \leq 0.05 \mathrm{Vs}$ Al administered group; ANOVA (F-values) ${ }^{\circledR}:$ Significant at $5 \%$ level

Table 4: Effectiveness of SAC against aluminium treated rats in LPO and GSH in tissues

\begin{tabular}{|c|c|c|c|c|c|c|}
\hline \multirow[b]{2}{*}{ Treatments } & \multicolumn{3}{|c|}{$\begin{array}{l}\text { Lipid Peroxidation } \\
\text { (n mole MDA } \mathrm{mg}^{-1} \text { protein) }\end{array}$} & \multicolumn{3}{|l|}{$\begin{array}{l}\text { Glutathione } \\
\left(\mu \text { mole } g^{-1}\right)\end{array}$} \\
\hline & Liver & Kidney & Brain & Liver & Kidney & Brain \\
\hline Control & $0.45 \pm 0.02$ & $0.66 \pm 0.03$ & $1.08 \pm 0.05$ & $7.20 \pm 0.39$ & $7.13 \pm 0.39$ & $7.02 \pm 0.38$ \\
\hline $\mathrm{Al}$ & $1.31 \pm 0.07^{\#}$ & $1.88 \pm 0.10^{\#}$ & $2.18 \pm 0.12^{\#}$ & $5.02 \pm 0.27^{\#}$ & $4.81 \pm 0.26^{\#}$ & $4.76 \pm 0.26^{\#}$ \\
\hline $\mathrm{Al}+\mathrm{SAC}_{25}$ & $0.67 \pm 0.03 *$ & $1.62 \pm 0.08 *$ & $1.47 \pm 0.08 *$ & $6.50 \pm 0.35^{*}$ & $6.90 \pm 0.38 *$ & $6.78 \pm 0.37 *$ \\
\hline $\mathrm{Al}+\mathrm{SAC}_{50}$ & $0.63 \pm 0.03 *$ & $1.50 \pm 0.08 *$ & $1.35 \pm 0.07 *$ & $6.70 \pm 0.37 *$ & $6.90 \pm 0.38 *$ & $6.80 \pm 0.37 *$ \\
\hline $\mathrm{Al}+\mathrm{SAC}_{100}$ & $0.59 \pm 0.03 *$ & $1.40 \pm 0.07 *$ & $1.34 \pm 0.07 *$ & $6.70 \pm 0.37 *$ & $7.10 \pm 0.39 *$ & $6.98 \pm 0.38 *$ \\
\hline Anova & $70.60^{@}$ & $37.90^{@}$ & $28.80^{@}$ & $6.41^{@}$ & $8.73^{@}$ & $8.51^{@}$ \\
\hline
\end{tabular}

(F-Value)Values are mean $\pm \mathrm{SE}, \mathrm{N}=6 .^{*}: \mathrm{p} \leq 0.05 \mathrm{Vs}$ control group, ${ }^{*}: \mathrm{p} \leq 0.05 \mathrm{Vs} \mathrm{Al}$ administered group. ANOVA (F-values) ${ }^{\circledR}:$ Significant at $5 \%$ level

Table 5: Effect of SAC extract against aluminum treated rats in total and esterified cholesterol in tissues

\begin{tabular}{|c|c|c|c|c|c|c|}
\hline \multirow[b]{2}{*}{ Treatments } & \multicolumn{3}{|c|}{$\begin{array}{l}\text { Total Cholesterol } \\
(\mathrm{mg} / 100 \mathrm{mg})\end{array}$} & \multicolumn{3}{|c|}{$\begin{array}{l}\text { Esterified Cholesterol } \\
(\mathrm{mg} / 100 \mathrm{mg})\end{array}$} \\
\hline & Liver & Kidney & Brain & Liver & Kidney & Brain \\
\hline Control & $0.12 \pm 0.006$ & $0.11 \pm 0.006$ & $0.98 \pm 0.05$ & $0.06 \pm 0.003$ & $0.03 \pm 0.002$ & $0.16 \pm 0.008$ \\
\hline $\mathrm{Al}$ & $1.21 \pm 0.066^{\#}$ & $0.75 \pm 0.041^{\#}$ & $2.95 \pm 0.16^{\#}$ & $0.20 \pm 0.011^{\#}$ & $0.15 \pm 0.008^{\#}$ & $0.65 \pm 0.036^{\#}$ \\
\hline $\mathrm{Al}+\mathrm{SAC}_{25}$ & $0.49 \pm 0.027 *$ & $0.51 \pm 0.028 *$ & $2.40 \pm 0.13^{*}$ & $0.15 \pm 0.008 *$ & $0.10 \pm 0.005 *$ & $0.55 \pm 0.030^{*}$ \\
\hline $\mathrm{Al}+\mathrm{SAC}_{50}$ & $0.47 \pm 0.025 *$ & $0.44 \pm 0.024 *$ & $2.33 \pm 0.12 *$ & $0.14 \pm 0.008 *$ & $0.10 \pm 0.005 *$ & $0.48 \pm 0.026 *$ \\
\hline $\mathrm{Al}+\mathrm{SAC}_{100}$ & $0.43 \pm 0.023^{*}$ & $0.44 \pm 0.24 *$ & $2.21 \pm 0.12 *$ & $0.11 \pm 0.006^{*}$ & $0.09 \pm 0.004$ & $0.47 \pm 0.026^{*}$ \\
\hline Anova & $148.00^{\Theta}$ & $83.50^{@}$ & $41.10^{@}$ & $53.30^{@}$ & $63.40^{@}$ & $55.10^{@}$ \\
\hline
\end{tabular}

(F-Value): Values are mean $\pm \mathrm{SE}, \mathrm{N}=6$. $^{\#}: \mathrm{p} \leq 0.05 \mathrm{Vs}$ control group, $*: \mathrm{p} \leq 0.05 \mathrm{Vs} \mathrm{Al}$ administered group. ANOVA (F-values) ${ }^{\circledR}:$ Significant at 5 $\%$ level 
Am. J. Biochem. \& Biotech., 7 (2): 74-83, 2011

Table 6 Effectiveness of SAC against aluminum treated rats in Metal concentration $(\mu \mathrm{g} / \mathrm{g})$ in tissues

\begin{tabular}{llll}
\hline Treatments & Liver & Kidney & Brain \\
\hline Control & $12.50 \pm .91$ & $16.40 \pm 0.90$ & $13.20 \pm 0.71$ \\
$\mathrm{Al}$ & $34.10 \pm 1.88^{\#}$ & $42.20 \pm 2.32^{\#}$ & $37.61 \pm 2.07^{\#}$ \\
$\mathrm{Al}+\mathrm{SAC}_{25}$ & $21.76 \pm 1.20^{*}$ & $38.62 \pm 2.13$ & $36.42 \pm 2.01$ \\
$\mathrm{Al}+\mathrm{SAC}_{50}$ & $19.51 \pm 1.07^{*}$ & $29.76 \pm 1.64^{*}$ & $30.00 \pm 1.65^{*}$ \\
$\mathrm{Al}+\mathrm{SAC}_{100}$ & $13.90 \pm 0.76^{*}$ & $20.91 \pm 1.15^{*}$ & $28.76 \pm 1.58^{*}$ \\
Anova (F Value) & $61.1^{@}$ & $49.4^{@}$ & $40.1^{@}$ \\
\hline
\end{tabular}

Values are mean \pm S.E., $\mathrm{N}=6 .{ }^{\#} \mathrm{P} \leq 0.05$ vs control group, ${ }^{*} \mathrm{P} \leq 0.05 \mathrm{vs} \mathrm{Al}$ administered group. ANOVA (F values) @ $=$ Significant at $5 \%$ level

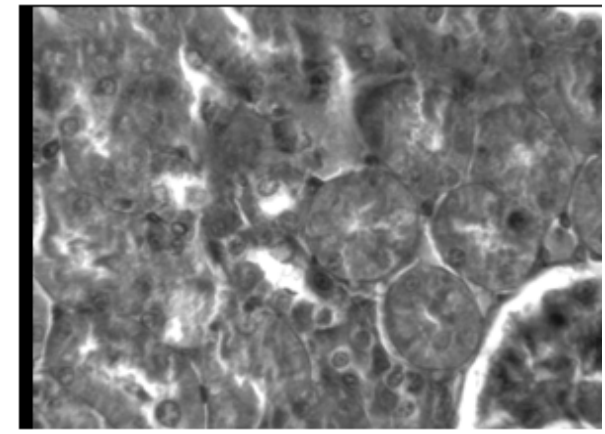

Fig. 4: $\mathrm{Al}\left(\mathrm{NO}_{3}\right)_{3}+\mathrm{SAC}_{100}$ showed compact glomeruli and well formed renal tubules $(\mathrm{X} 400)$

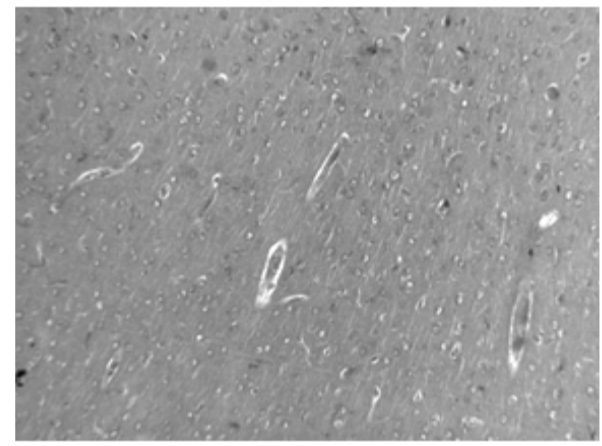

Fig. 5: Al exposure caused neurofibrillary tangles with vacuolation (X100)

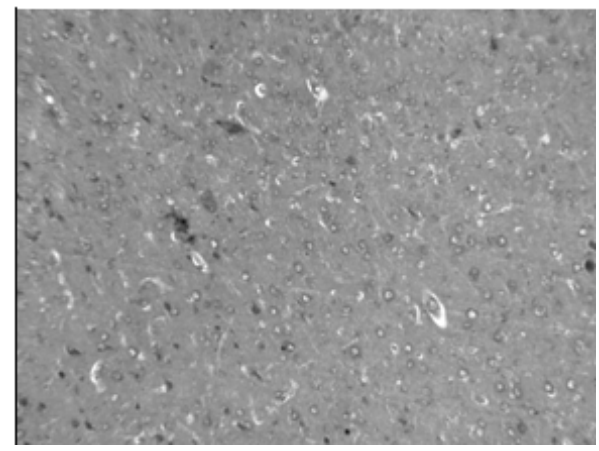

Fig. 6: $\mathrm{Al}\left(\mathrm{NO}_{3}\right)_{3}+\mathrm{SAC}_{100}$ showed well formed layers, epineurium, perineurium and endoneurium (X100)
After Al exposure neuronal degeneration and glial cell (microglia) proliferation was observed in brain, pyknotic neurons were noticed. Cerebellar atrophy was also observed (Fig. 5). Lower dosed showed mild improvement in Purkinje cells. Astrocytes led to scattered neurons with reduced vacuolation in granule cell layer. The oligodendrites were reduced in size. Treatment with highest dose resulted in almost normal histoarchitecture depicting all the normal layers and Purkinje neurons. There was significant loss of vacuolization in neurons. Prominent nuclei were seen in Schwann cells. Fibroblasts and glial cells showed more or less normal structure (Fig. 6).

\section{DISCUSSION}

The present study was undertaken to determine whether SAC can prevent and/or reduce Al-induced oxidative stress by examining different biochemical parameters of oxidative damage in the serum, the liver, kidney and brain in rats.

Our results clearly showed that there was a significant biochemical and histopathological changes suggesting strong prooxidant activity inspite of its nonredox status (Exley, 2004). Its toxicity may be mediated by free radical generation and alterations in antioxidant enzymes in vivo and in vitro (Tabaldi et al., 2009), which caused neurotoxicity (Kumar et al., 2009; Rodella et al., 2008), nephrotoxicity (Mahieu et al., 2009) and hepatotoxicity (Kutlubay et al., 2007).

Activities of serum AST, ALT, LDH, urea and creatinine were increased after toxicant administration. Changes in these enzymatic activities may be due to the leakage of these enzymes from the liver cytosol into the blood stream and/or liver dysfunction. These abnormalities were prevented by supplementation of $\mathrm{SAC}$, perhaps due to its role in stabilizing the cell membrane and protect the liver from free radicalmediated liver cell toxicity various authors (AlHashem, 2009a; Yousef, 2004; Nayak et al., 2006). Mohamed and Awad (2008) reported similar findings after $\mathrm{Al}$ exposure. $\mathrm{LDH}$ is a hydrogen transfer enzyme is used in the diagnosis of liver damage. Other metals like cadmium also increased the serum transaminases (Al-Hashem et al., 2009; Amin1 et al., 2006). Results 
of the present study clearly depicted that $\mathrm{Al}$ administration enhanced concentration of this soluble enzyme significantly. The activity of this enzyme is also increased by feedback mechanism as it is involved in glucose metabolism. It is used as marker of $\mathrm{Al}$ toxicity. Similar finding was noted by El-Demerdash (2004); Yousef (2004) and Anane and Creppy (2001). These values were restored near to control after SAC treatment. SAC restored the values of AST, ALT, LDH in serum along with improved histological and transmission electron microscopic structure against chromium and acetaminophen induced toxicity (Kalayarasan et al., 2008; Hsu et al., 2006).

Cholesterol, TG and creatinine were increased after toxicant exposure. The increase in serum TG is possibly due to hypoactivity of lipoprotein lipase in blood vessels which breaks up TG. High serum cholesterol level may be due to hepatic dysfunction (AlHashem, 2009a; Kojima et al., 2004; Kantola et al., 1998). The cholesterol content in brain was higher in $\mathrm{Al}$ fed rats (Pandya et al., 2004). The decreased value of lipid levels on the administration of SAC may be due to hypolipidemic effect (Chang and Johnson, 1980). The elevation in creatinine and urea levels in $\mathrm{Al}$ treated rats in the present study reveals significant damage in kidney. These findings are supported by various authors (Afifi, 2010; Mahieu et al., 2009; Al-Hashem et al., 2009; Rudenko et al., 1998). Toxicant administration enhanced the LPO in liver, kidney and brain but caused a significant decline in the GSH level. Elevation of LPO in liver, brain and kidney was evident by the increased production of TBARS, which suggests participation of free-radical induced oxidative cell injury in mediating the toxicity of $\mathrm{Al}$ (Al-Hashem, 2009a; Newairy et al., 2009; Anane and Creppy, 2001). GSH play an important role in the detoxification and metabolism of many xenobiotic compounds. Several pathologies that affect the nervous system involve oxidative stress, possibly associated with the decrease in glutathione content. The decrease in SH group of GSH content was also found in the studies of Dua and Gill (2001). GSH is the brain masters antioxidant and protect neurons from the harmful effects of free radicals. Al caused significant decrease in the GSH in brain and liver. Metals like as Cadmium, Cisplatin, lead and mercury induced oxidative stress by depleting the major intracellular antioxidant, glutathione in liver, kidney and brain (Afifi, 2010; Al-Hashem et al., 2009; Amin et al., 2006) therapy SAC provoked considerable recovery. SAC restored activities of enzymic antioxidants (SOD, CAT, GPx), non-enzymic antioxidants (vitamin $\mathrm{C}$ and vitamin E), GSH, LPO and reactive oxygen species in liver and serum of against chromium, alcohol and acetaminophen induced group (Kalayarasan et al., 2008; Yan and Yin 2007; Hsu et al., 2006).

Aluminum neurotoxicity is due to the contribution of the $\mathrm{Al} 3+$ ion to iron-induced neuronal oxidative damage. The two metals are expected to act synergistically, aluminum coordination to the neuronal membrane facilitating attacks by iron-induced free radicals, whereas membrane oxidation in turn increases aluminum binding, thus, aggravating oxidation (Berthon, 2002). Brain membranes are not only based on the presence of polyunsaturated fatty acids and phospholipids components, but also that of molecules with a high content of lipid/protein ratio (like e.g., myelin) supporting the fact that ions without redox capacity can stimulate lipid peroxidation by promoting phase separation and membrane rigidification (Christen, 2000).

A significant decrease was observed in the AchE of fore, mid and hind brain after $\mathrm{Al}$ exposure which may interfere with either synthesis of AchE or inhibit choline uptake by synaptosomes. The higher reduction in AchE activity of brain may suggest that this part of brain is much more susceptible to metal intoxication. Al also may bind with the active site of AchE hence, decreases the activity of AChE in all parts of the brain. When this enzyme is inhibited Ach is not hydrolyzed and accumulates in cholinergic sites causing alteration in the normal nervous system function (Moshtaghi et al., 1999). Kumar et al. (2009) reported a significant decrease in the AchE activity in brain of rats after $\mathrm{Al}$ exposure. Treatment with extract showed neuroprotection by enhancing AchE in all parts of brain.

Activity of ALAD in blood and ALAS in brain was significantly decreased after Al exposure. The ALAS, is first and the rate-limiting enzyme of heme biosynthesis which is localized in mitochondria. The enzyme requires glycine and succinyl Coenzyme $\mathrm{A}(\mathrm{CoA})$ as substrates and pyridoxal 5'-phosphate as a cofactor. ALAD activity is second enzyme of the haem biosynthesis pathway. The reduced level of $\mathrm{Hb}$ can be associated with hemolysis or disturbances in heme biosynthesis as a result of inhibit linking of iron with heme and drop in activity of ALAD and ALAS taking part in heme biosynthesis. Lead and mercury also inhibited ALAD and cause neurotoxicity (Rose et al., 2008). SAC therapy improved the activity of ALAD blood and ALAS by protecting dysfunction of mitochondria, ER, disruption of calcium homeostasis and preventing its accumulation in macrophages in hepatocyte organelles such as lysosomes vesicles (Bogdanovic et al., 2008). 
The efficiency of SAC was perhaps due to the presence of these sulfur-containing biologically active lipophilic compounds, which might have chelated $\mathrm{Al}$ by the formation of ionic bonds between sulfur containing compounds and enhanced its excretion from the body. These easily permeate through phospholipid membranes (Miron et al., 2000) and reduce intracellular $\mathrm{Al}$ thus enhancing the endogenous antioxidant defenses thereby preventing reactive oxygen species formation and lipid peroxidation. It also protects histological structure thereby depleting functional improvement to some extent. The present study indicates that SAC extracted from garlic has antioxidant and hypolipidemic effects., Sallylcysteine, such as its high water solubility and stability, suggest a broad spectrum of potential therapeutic actions in different experimental models of systemic and central diseases, this aged garlic extract compound is a promising candidate to be clinically and experimentally tested in neurological degenerative events with oxidative components.

\section{CONCLUSION}

Aluminum has adverse effects on human health. Our results demonstrate that $\mathrm{Al}$ alters biochemical parameters induces oxidative stress and histopathological alterations Consequently, attention should be paid to the sources of aluminum in food, water and medical drugs. SAC therapy after $\mathrm{Al}$ exposure, minimized Al-associated hazards. Therefore, SAC could be beneficial for reducing aluminum toxicity. Further studies are required using a human population, to confirm these protective effects.

\section{ACKNOWLEDGMENT}

This study was supported by DST, New Delhi for financial assistance (SR/WOS-A/LS-153/2007). The author is thankful to Prof. Sangeeta Shukla, Dr. Monika Bhadauria, Jiwaji University, Gwalior (MP) for lab facility.

\section{REFERENCES}

Afifi, M.E.M., 2010. Effect of camel's milk on cisplatin-induced nephrotoxicity in Swiss Albino Mice. Am. J. Biochem. Biotechnol., 6: 141-147. DOI: 10.3844/ajbbsp.2010.141.147

Al-Hashem, F., M. Dallak, N. Bashir, M. Abbas and R. Elessa et al., 2009. Camel's milk protects against cadmium chloride induced toxicity in white albino rats. Am. J. Pharmacol. Toxicol., 4: 107-117. DOI: 10.3844/ajptsp.2009.107.117
Al-Hashem, F.H., 2009a. Camel's milk protects against aluminum chloride-induced toxicity in the liver and kidney of white albino rats. Am. J. Biochem. Biotechnol., $\quad$ 5: 98-108. DOI: 10.3844/ajbbsp.2009.98.108

Al-Hashem, F.H., 2009b. Camel's milk alleviates oxidative stress and lipid peroxidation induced by chronic aluminum chloride exposure in rat's testes. Am. J. Applied Sci., 6: 1868-1875. DOI: 10.3844/ajassp.2009.1868.1875

Amer, M., M. Taha and Z. Tosson, 1980. The effect of aqueous garlic extract on the growth of dermatophytes. Int. J. Dermatol., 19: 285-287. PMID: 7390694

Amin, A., A.A. Hamza, S. Daoud and W. Hamza, 2006. Spirulina protects against cadmium-induced hepatotoxicity in rats. Am. J. Pharmacol. Toxicol., 1: 21-25. DOI: 10.3844/ajptsp.2006.21.25

Anane, R. and E.E. Creppy, 2001. Lipid peroxidation as pathway of aluminum cytotoxicity in human skin fibroblast cultures: Prevention by superoxide dismutase + catalase and vitamins E and C. Hum. Exp. Toxicol., 20: 477-481. PMID: 11776410

Banerjee, S.K., P.K. Mukherjee and S.K. Maulik, 2003. Garlic as an antioxidant: The good, the bad and the ugly. Phytother. Res., 17: 97-106. PMID: 12601669

Berlin, A. and A.H. Schaller, 1974. European standarized method foor the determination of $\delta$ aminolevulinic acid dehydratase activity in blood. Zeitschrif fur Klinishe Chemie Klinische Biochemie., 12: 389-390. PMID: 4428852

Berthon, G., 2002. Aluminum speciation in relation to aluminum bioavailability, metabolism and toxicity. Coord Chem. Rev., 228: 319-341. DOI: 10.1016/S0010-8545(02)00021-8

Bihagi, S.W., M. Sharma, A.P. Singh and M. Tiwari, 2009. Neuroprotective role of Convolvulus pluricaulis on aluminium induced neurotoxicity in rat brain. J. Ethnopharmacol., 124: 409-415. PMID: 19505562

Bogdanovic, M., A.B. Janeva and P. Bulat, 2008. Histopathological changes in rat liver after a single high dose of aluminium. Arch. Ind. Hyg. Toxicol., 59: 97-101. PMID: 18573746

Bordia, A. and S.K. Verma, 1980. Effect of garlic feeding on regression of experimental atherosclerosis in rabbits. Artery, 7: 428-437. PMID: 7213027

Bordia, A., H.C. Bansal, S.K. Arora and S.V. Singh, 1975. Effect of the essential oils of garlic and onion on alimentary hyperlipemia. Atherosclerosis, 21: 15-19. PMID: 1131298 
Brehe, J.E. and H.B. Bruch, 1976. Enzymatic assay for glutathione. Anal. Biochem., 74: 189-197. PMID: 962073

Chang, M.L. and M.A. Johnson, 1980. Effect of garlic on carbohydrate metabolism and lipid synthesis in rats. J. Nutr., 110: 931-936. PMID: 6989965

Christen, Y., 2000. Oxidative stress and Alzheimer disease. Am. J. Clin. Nutr., 71: 621S-9S. PMID: 10681270

Craig, W. and L. Beck, 1999. Phytochemicals: Health protective effects. Can. J. Diet. Pract. Res., 60: 7884. PMID: 11551345

Das, G.A., P.C. Dhara, S.A. Dhundasi and K.K. Das, 2009. Effect of garlic (Allium sativum) on nickel II or chromium VI induced alterations of glucose homeostasis and hepatic antioxidant status under sub-chronic exposure conditions. J. Basic. Clin. Physiol. Pharmacol., 20: 1-14. PMID: 19601391

Das, G.A., S.N. Das, S.A. Dhundasi and K.K. Das, 2008. Effect of garlic (Allium sativum) on heavy metal (nickel II and chromium VI) induced alteration of serum lipid profile in male albino rats. Int. J. Environ. Res. Public Health, 5: 147-151. PMID: 19139532

Dua, R. and K.D. Gill, 2001. Aluminium phosphide exposure: implications on rat brain lipid peroxidation and antioxidant defence system. J. Pharmacol. Toxicol., 189: 315-319. PMID: 11903958

El-Demerdash, F.M., 2004. Antioxidant effect of vitamin $\mathrm{E}$ and selenium on lipid peroxidation, enzyme activities and biochemical parameters in rats exposed to aluminium. J. Trace. Elem. Med. Biol., 18: 113-121. PMID: 15487771

Ellman, G.L., K.D. Courthey, V. Anders, R.M. FeatherStone, 1961. A new and rapid colorimetric determination of acetylcholinesterase activity. Biochem. Pharmacol., 7: 88-95. PMID: 13726518

Exley, C., 2004. The pro-oxidant activity of aluminum. Free Radic. Biol. Med., 36: 380-387. PMID: 15036357

Goulb, M.S., B. Han, C.L. Keen and M.E. Gershwin, 1995. Effects of dietary aluminum excess and manganese deficiency on neurobehavioral endpoints in adult mice. Toxicol. Applied Pharmacol., 112: 154-160. PMID: 1733044

Hsu, C.C., C.C. Lin, T.S. Liao and M.C. Yin, 2006. Protective effect of s-allyl cysteine and s-propyl cysteine on acetaminophen-induced hepatotoxicity in mice. Food Chem. Toxicol., 44: 393-397. PMID: 16181716

Hussain, S.P., L.N. Jannu and A.R. Roa, 1990. Chemopreventive action of garlic on methylcholanthrene-induced carcinogenesis in the uterine cervix of mice. Cancer Lett., 49: 175-180. PMID: 2306712

Isaacson, R.L. and K.F. Jensen, 1994. The Vulnerable Brain and Environmental Risks: Toxins in Air and Water. 1st Edn., Plenum Press, New York, London, ISBN: 0306446111, pp: 384.

Ishige, K., N. Takagi, T. Imai, W.D. Rausch and Y. Kosuge et al., 2007. Role of caspase-12 in amyloid beta-peptide-induced toxicity in organotypic hippocampal slices cultured for long periods. J. Pharmacol. Sci., 104: 46-55. DOI: 0.1254/jphs.FP0061533

Jain, R.C. and C.R. Vjas, 1975. Garlic in alloxaninduced diabetic rabbits. Am. J. Clin. Nutr., 28: 684-685. PMID: 1146717

Johnson, M.G. and R.H. Vaughn, 1969. Death of Salmonella typhimurium and Escherichia coli in the presence of freshly reconstituted dehydrated garlic and onion. Applied Microbiol., 17: 903-905. PMID: 4894725

Kalayarasan, S., N. Sriram, A. Sureshkumar and G. Sudhandiran, 2008. Chromium (VI)-induced oxidative stress and apoptosis is reduced by garlic and its derivative S-allylcysteine through the activation of Nrf2 in the hepatocytes of Wistar rats. J. Applied Toxicol., 28: 908-919. PMID: 18548744

Kan, W.C., C.C. Chien, C.C. Wu, S.B. Su and J.C. Hwang et al., 2010. Comparison of low-dose deferoxamine versus standard-dose deferoxamine for treatment of aluminium overload among haemodialysis patients. Nephrol. Dial. Transplant., 25: 1604-1608. PMID: 19948879

Kantola, T., K.T. Kivisto and P.J. Neuvonen, 1998. Grapefruit juice greatly increases serum concentrations of lovastatin and lovastatin acid. Clin. Pharmacol. Therapeut., 63: 397-402. PMID: 9585793

Kojima, M., T. Mausi, K. Nemoto and M. Degawa, 2004. Lead nitrate-induced development of hypercholesterolemia in rats: sterol-independent gene regulation of hepatic enzymes responsible for cholesterol homeostasis. Toxicol. Lett., 154: 35-44. PMID: 15475176

Kosuge, Y., T. Sakikubo, K. Ishige and Y. Ito, 2006. Comparative study of endoplasmic reticulum stress-induced neuronal death in rat cultured hippocampal and cerebellar granule neurons. Neurochem. Int., 49: 285-93. PMID: 16545889

Kumar, A., S. Dogra and A. Prakash, 2009. Protective effect of curcumin (Curcuma longa), against aluminium toxicity: Possible behavioral and biochemical alterations in rats. Behav. Brain Res., 205: 384-390. PMID: 19616038 
Kutlubay, R., E.O. Oguz, C. Guven, B. Can and Z. Sinik et al., 2007. Histological and ultrastructural evidence for protective effects on aluminiuminduced kidney damage by intraperitoneal administration of alpha-tocopherol. Int. J. Toxicol., 26: 95-101. PMID: 17454249

Lee, J.H., H.S. Kang and J. Roh, 1999. Protective effects of garlic juice against embryotoxicity of methylmercuric chloride administered to pregnant Fischer 344 rats. Yonsei Med. J., 40: 483-489. PMID: 10565261

Mahieu, S., M.C. Contini, M. Gonzalez and N. Millen, 2009. Melatonin reduces oxidative damage induced by aluminium in rat kidney. Toxicol. Lett., 190: 915. PMID: 19539013

Maines, M.D., 1980. Regional distribution of the enzymes of haem biosynthesis and the inhibition of 5-aminolaevulinate synthase by manganese in the rat brain. J. Biochem., 190: 315-321. PMID: 6894089

Metwally, M.A.A., 2009. Effect of Garlic (Allium sativum) on Some Heavy Metal (Copper and Zinc) Induced Alteration in Serum Lipid Profile of Oreochromis niloticus. World J. Fish Marine Sci., 1 : 01-06. http://idosi.org/wjfms/wjfms 1\%281\%2909/1.pdf

Miron, T., A. Rabinkov, D. Mirelman, M. Wilchek and L. Weiner, 2000. The mode of action of allicin: Its ready permeability through phospholipid membranes may contribute to its biological activity. Biochim. Biophys. Acta, 1463: 20-30. PMID: 10631291

Mohamed, M.A. and S.M. Awad, 2008. Effect of Nigella Sativa Oil on Some Hematological values in Aluminium -treated rats. Autralian J. Basic Applied $\quad$ Sci., $\quad 2$ : 115-1164. http://insipub.net/ajbas/2008/1157-1164.pdf

Morihara, N., I. Sumioka, N. Ide, T. Moriguchi and N. Uda et al., 2006. Aged garlic extract maintains cardiovascular homeostasis in mice and rats. J. Nutr., 136: 777S-781. PMID: 16484562

Moshtaghi, A.A., S. Rahimi and M. Messripour, 1999. Aluminium administration on acetylcholinestrase activity of different regions of rat brain. Med. J. Islamic Acad. Sci., 12: 105-108. www.medicaljournalias.org/.../Belge/MostaghiePUENSCHDMQ66454. pdf

Mostaghie, A.A. and A.W. Skillen, 1986. Binding of aluminum to transferring and lactoferrin.Biochem. Soc. Trans., 14: 916-917. http://www.medicaljournalias.org/Belgelerim/Belge/MoshtaghieIEJSCHQVR B99054.pdf
Nayak, P., S.K. Das and D.N. Vasudavan, 2006. Role of ethanol on aluminum induced biochemical changes on rat brain. Indian J. Clin. Biochem., 21: 53-57. DOI: $10.1007 / \mathrm{BF} 02912912$

Newairy, A.S., A.F. Salama, H.M. Hussien and M.I. Yousef, 2009. Propolis alleviates aluminiuminduced lipid peroxidation and biochemical parameters in male rats. Food. Chem. Toxicol., 47: 1093-1098. PMID: 19425229

Nishiyama, N., T. Moriguchi, N. Morihara and H.Saito, 2001. Ameliorative effect of S-allylcysteine, a major thioallyl constituent in aged garlic extract, on learning deficits in senescence-accelerated mice. J. Nutr., 131: 1093S-1095S. PMID: 11238823

Pandya, J.D., K.R. Dave and S.S. Katyare, 2004. Effect of long-term aluminum feeding on lipid/phospholipid profiles of rat brain myelin. Lipids Health Dis., 3: 13-13. DOI: 10.1186/1476511X-3-13

Prakash, A. and A. Kumar, 2009. Effect of N-acetyl cysteine against aluminium-induced cognitive dysfunction and oxidative damage in rats. Basic Clin. Pharmacol. Toxicol., 105: 98-104. PMID: 19389043

Reitman, S. and A.S. Frankel, 1957. A colorimetric method for the determination of serum glutamic oxalacetic and glutamic pyruvic transaminases. Am. J. Clin. Pathol., 28: 56-63. PMID: 13458125

Riley, V., 1960. Adaptation of orbital bleeding technic to rapid serial blood studies. Proc. Soc. Exp. Biol. Med., 104: 5154. PMID: 13741689

Rodella, L.F., F. Ricci, E. Borsani, A. Stacchiotti and E. Fogllo et al., 2008. Aluminium exposure induces Alzheimer's disease-like histopathological alterations in mouse brain. Histol. Histopathol., 23: 433-439. PMID: 18228200

Rose, S., S. Melnyk, A. Savenka, A. Hubanks and S. Jernigan et al., 2008. The frequency of polymorphisms affecting lead and mercury toxicity among children with autism. Am. J. Biochem. Biotechnol., 4: 85-94. DOI: 10.3844/ajbbsp.2008.85.94

Rudenko, S.S., B.M. Bodnar, O.L. Kukharchuk, V.M. Mahalias and M.M. Rybshchka et al., 1998. Effect of selenium on the functional state of white rat kidney in aluminum-cadmium poisoning. Ukr. Biokhim. Zh. J., 70: 98-105. PMID: 10402657

Senapati, S.K., S. Dey, S.K. Dwivedi and D. Swarup, 2001. Effect of garlic (Allium sativum L.) extract on tissue lead level in rats. J. Ethnopharmacol., 76: 229-232. PMID: 11448543 
Sharma, S.K. and C.R. Krishna Murthy, 1968. Production of lipid peroxides by brain. J. Neurochem., 15: 147-149. PMID: 5637724

Snedecor, G.W. and W.G. Cochran, 1989. Statistical Method. 8th Edn., Wiley-Blackwell, Iowa State University Press, Ames, ISBN: 0813815614, pp: 503.

Stark, M., J. Zubareb, R. Jacovovitz, Y. Schwartz and Y. Lerman et al., 2009. HO-1 and VEGF gene expressions are time dependant during exposure to welding fumes. Cytokine, 46: 290-295. PMID: 19303319

Tabaldi, L.A., D. Cargnelutti, J.F. Goncalves, L.B. Pereira and G.Y. Castro et al., 2009. Oxidative stress is an early symptom triggered by aluminum in Al-sensitive potato plantlets. Chemosphere, 76: 1402-1409. PMID: 19570563

Tandon, S.K., S. Singh and S. Prasad, 2001. Influence of garlic on the disposition and toxicity of lead and cadmium in the rat. Pharmaceut. Biol., 39: 450454. DOI: $10.1076 /$ phbi.39.6.450.5887

Verstraeten, S.V., L. Aimo, P.I. Oteiza, 2008. Aluminium and lead: molecular mechanisms of brain toxicity. Arch. Toxicol., 82: 789-802. PMID: 18668223
Yan, S.L. and M.C. Yin, 2007. Protective and alleviative effects from 4 cysteine-containing compounds on ethanol-induced acute liver injury through suppression of oxidation and inflammation. J. Food Sci., 72: 511-515. PMID: 17995665

Yousef, M.I. and A.F. Salama, 2009. Propolis protection from reproductive toxicity caused by aluminium chloride in male rats. Food Chem. Toxicol., 47: 1168-1175. PMID: 19425234

Yousef, M.I., 2004. Aluminium-induced changes in hemato-biochemical parameters, lipid peroxidation and enzyme activities of male rabbits: Protective role of ascorbic acid. Toxicology, 199: 47-57. PMID: 15125998

Zlatkis, A., B. Zak and A.J. Boyle, 1953. A new method for the direct determination of serum cholesterol. J. Lab. Clin. Med., 41: 486-492. PMID: 13035283 